\title{
Effect of Lung Inflation on Pulmonary Diffusing Capacity at Rest and Exercise*
}

\author{
John M. Miller and Robert L. Johnson, JR. $\dagger$ \\ (From the Cardiopulmonary Division, Department of Internal Medicine, University of Texas \\ Southwestern Medical School, Dallas, Texas)
}

Steady state measurements of the diffusing capacity of the lung are made at operational lung volume, whereas measurements by the breath-holding method are customarily made at full inspiration. The effect of lung inflation on diffusing capacity must be taken into account before the steady state and breath-holding methods can be validly compared.

At rest the single breath diffusing capacity of the lung for $\mathrm{CO}\left(\mathrm{DL}_{\mathrm{CO}}\right)$ increases as the lung is inflated, presumably due to expansion of the alveolar-capillary surface; the volume of blood in the pulmonary capillary bed does not increase (1-5). During exercise the diffusing capacity, measured at full inspiration, increases with pulmonary blood flow, and this increase is associated with expansion of the pulmonary capillary blood volume (1, $2,6,7)$. It is not known how changing the lung inflation affects the expansion of the pulmonary capillary surface and blood volume during exercise. To investigate this problem we measured $\mathrm{DL}_{\mathrm{CO}}$ by the breath-holding technique at different lung volumes at rest and exercise in five healthy adults. Measurements were made at two different alveolar oxygen tensions to calculate membrane diffusing capacity for carbon monoxide ( $\mathrm{DM}_{\mathrm{co}}$ ) and pulmonary capillary blood volume ( $\mathrm{Vc}$ ) by the method of Roughton and Forster (8).

We have compared our measurements of diffusing capacity obtained by the breath-holding method with steady state measurements from other laboratories.

* Submitted for publication July 6, 1965 ; accepted December 16, 1965.

Supported by grants from the U.S. Public Health Service (HE 07744 and HE 06296).

† Address requests for reprints to Dr. Robert L. Johnson, Jr., Dept. of Internal Medicine, University of Texas Southwestern Medical School, Dallas, Texas 75235.

\section{Methods}

Apparent diffusing capacity of the lung for CO (DLco) and pulmonary capillary blood flow $(\dot{Q} \mathrm{c})$ were measured in five normal subjects (Table I) at approximately 200 $\mathrm{ml}$ below total lung capacity (TLC) and at approximately $50 \%$ of TLC. The breath-holding method of Ogilvie, Forster, Blakemore, and Morton (2), as modified by Lawson and Johnson (9), was used to measure DLco and Qc simultaneously. The subject inhaled to full inspiration, and the mouthpiece was switched into a bag-box system. He next exhaled fully to near residual volume and then inspired the gas mixture. A solenoid valve limited the inspiration either at $200 \mathrm{ml}$ below full inspiration or at approximately functional residual capacity (FRC). Alveolar volume during breath holding was measured by neon dilution. The single breath neon dilution method to determine alveolar volume was preferred to either the nitrogen washout method or the plethysmographic method because the subject was not obliged to expire to exactly reproducible residual volume during the treadmill exercise. Furthermore, a separate alveolar volume was obtained for each diffusing capacity measurement. In young healthy adults the neon dilution method gives highly comparable values to the plethysmographic determination: for 11 young adults studied in our laboratory the mean total lung volume was $7.20 \pm 1.10 \mathrm{~L}$ at body temperature and pressure, saturated with water, (BTPS) by the neon method and $7.35 \pm 1.16 \mathrm{~L}$ by the plethysmograph. The slightly lower value for the neon method is largely explained by the fact that we had our subjects inspire $200 \mathrm{ml}$ less than their vital capacities for the neon determinations.

DLco, $\dot{Q} c$, and pulmonary tissue volume were estimated at rest from the line best fitting the exponential fall of

TABLE I

Physical characteristics of subjects

\begin{tabular}{ccccc}
\hline \hline Subject & Age & Height & Weight & $\begin{array}{c}\text { Body } \\
\text { surface } \\
\text { area }\end{array}$ \\
\hline & years & inches & pounds & $m^{2}$ \\
JM & 29 & 69 & 152 & 1.85 \\
AP & 29 & 68 & 183 & 1.97 \\
JT & 21 & 74 & 170 & 2.03 \\
GH & 17 & 71 & 146 & 1.84 \\
PG & 18 & 70 & 150 & 1.85 \\
Average & 23 & 70.4 & 160 & 1.91 \\
\hline
\end{tabular}


TABLE II

Lung diffusing capacity for $\mathrm{CO}$ at different

\begin{tabular}{|c|c|c|c|c|c|c|c|c|c|c|}
\hline \multirow[b]{3}{*}{ Subject } & \multicolumn{10}{|c|}{ Rest } \\
\hline & \multicolumn{5}{|c|}{ Low oxygen } & \multicolumn{5}{|c|}{ High oxygen } \\
\hline & $\bar{n}$ & VAt & PAO2 & $\mathrm{DL}$ & $\overline{\mathbf{Q}} \mathbf{c}$ & $\bar{n}$ & VAt & $\mathrm{PAO}_{\mathrm{AO}}$ & $D_{L}$ & $\dot{\mathrm{Q}} \mathrm{c}$ \\
\hline & & $m l$ & $m m \mathrm{Hg}$ & $\underset{m m ~ H g}{m l / m i n} /$ & $L / \min$ & & $m l$ & $m m \mathrm{Hg}$ & $\underset{m m ~}{\operatorname{ml} \mathbf{H g}}$ & $L / \min$ \\
\hline $\begin{array}{c}\text { At TLC } \\
\text { JM } \\
\text { JM } \\
\text { AP } \\
\text { JT } \\
\text { GH } \\
\text { PG }\end{array}$ & $\begin{array}{r}11 \\
5 \\
2 \\
3 \\
3\end{array}$ & $\begin{array}{l}5.58 \\
5.11 \\
6.15 \\
5.35 \\
5.14\end{array}$ & $\begin{array}{l}166 \\
169 \\
162 \\
155 \\
178\end{array}$ & $\begin{array}{l}24.1 \\
29.2 \\
35.5 \\
34.9 \\
32.1\end{array}$ & $\begin{array}{l}5.84 \\
3.99 \\
7.30 \\
5.16 \\
6.79\end{array}$ & $\begin{array}{r}10 \\
8 \\
4 \\
3 \\
3\end{array}$ & $\begin{array}{l}5.36 \\
5.12 \\
6.41 \\
5.44 \\
5.44\end{array}$ & $\begin{array}{l}658 \\
658 \\
653 \\
648 \\
627\end{array}$ & $\begin{array}{l}11.2 \\
14.1 \\
17.7 \\
17.1 \\
17.9\end{array}$ & $\begin{array}{l}4.69 \\
3.99 \\
7.71 \\
6.11 \\
6.79\end{array}$ \\
\hline $\begin{array}{c}\text { At FRC } \\
\text { JM } \\
\text { JM } \\
\text { AP } \\
\text { JT } \\
\text { GH } \\
\text { PG }\end{array}$ & $\begin{array}{l}7 \\
6 \\
2 \\
2 \\
3\end{array}$ & $\begin{array}{l}2.86 \\
2.45 \\
3.01 \\
2.67 \\
2.62\end{array}$ & $\begin{array}{l}142 \\
138 \\
119 \\
126 \\
146\end{array}$ & $\begin{array}{l}20.7 \\
26.7 \\
35.2 \\
31.2 \\
28.3\end{array}$ & $\begin{array}{l}5.39 \\
5.55 \\
8.02 \\
6.27 \\
5.21\end{array}$ & $\begin{array}{l}8 \\
8 \\
2 \\
2 \\
3\end{array}$ & $\begin{array}{l}2.96 \\
2.48 \\
3.28 \\
2.75 \\
2.72\end{array}$ & $\begin{array}{l}649 \\
638 \\
633 \\
617 \\
617\end{array}$ & $\begin{array}{l}10.5 \\
15.0 \\
17.0 \\
16.7 \\
16.6\end{array}$ & $\begin{array}{l}6.39 \\
5.00 \\
5.82 \\
5.54 \\
5.03\end{array}$ \\
\hline
\end{tabular}

* Abbreviations: $\mathrm{n}=$ number of determinations, $\mathrm{VA}_{\mathrm{A}}=$ alveolar volume measured from the single breath neon dilution, $\mathrm{P}_{\mathrm{A}_{\mathrm{O} 2}}=$ alveolar oxygen pressure at termination of breath holding, $\mathrm{DL}=$ lung diffusing capacity; $\dot{\mathrm{Q}} \mathrm{c}=$ pulmonary capillary blood flow. TLC $=$ total lung capacity, and FRC = functional residual capacity.

† Standard temperature, pressure, dry.

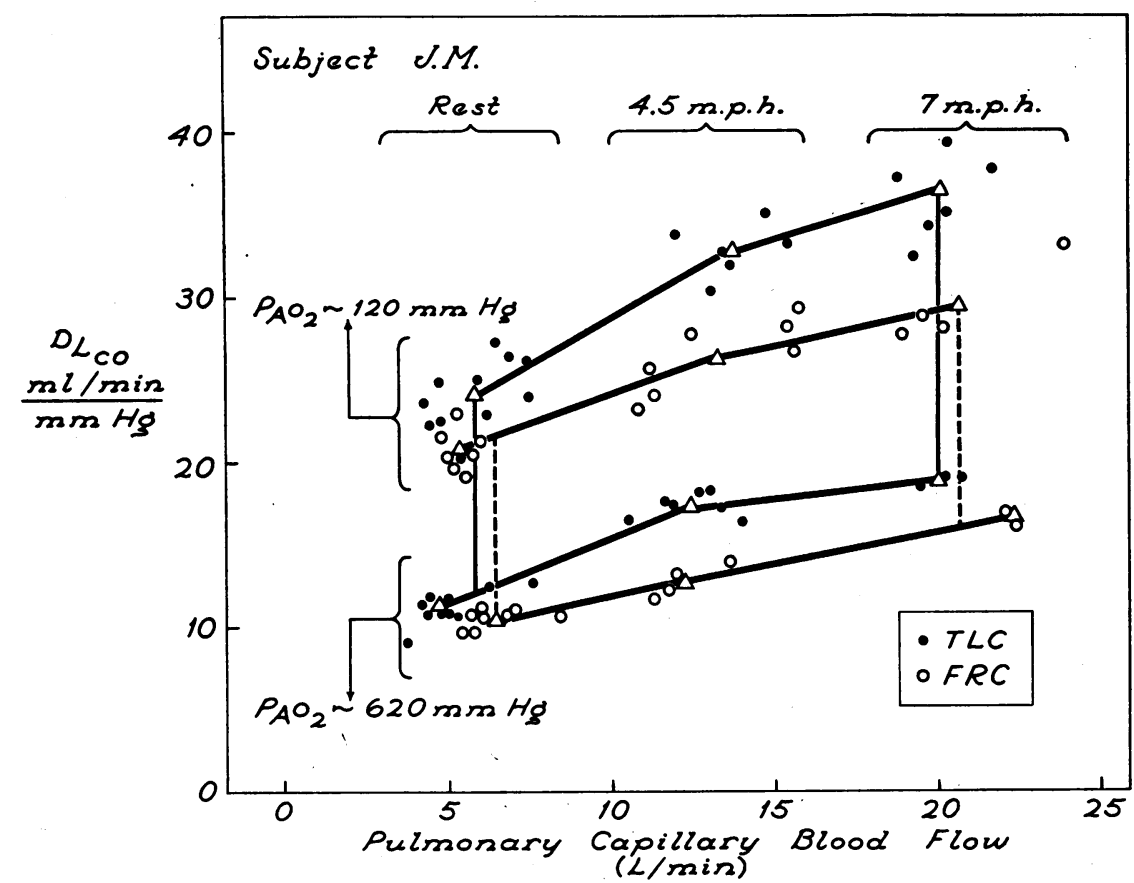

Fig. 1. The scatter of lung diffusing capacity for CO (Dlco) measured at DIFFERENT WORK LOADS AND AT DIFFERENT LUNG VOLUMES IN SUBJECT JM. The values used for estimating membrane diffusing capacity (DMco) and pulmonary capillary blood volume (Vc) at total lung capacity (TLC) are connected by the solid lines; those for functional residual capacity (FRC) by the dashed lines. $\mathrm{PAO}_{2}=$ alveolar oxygen tension. 
TABLE II

lung volumes at rest and during exercise*

\begin{tabular}{|c|c|c|c|c|c|c|c|c|c|}
\hline \multicolumn{10}{|c|}{ Exercise } \\
\hline \multicolumn{5}{|c|}{ Low oxygen } & \multicolumn{5}{|c|}{ High oxygen } \\
\hline $\bar{n}$ & VAt & $\mathbf{P}_{\text {AO2 }}$ & $D_{L}$ & $\dot{Q} \mathrm{c}$ & $\mathrm{n}$ & VAt & PAO: & DL & $\dot{\mathrm{Q}} \mathrm{c}$ \\
\hline & $m l$ & $m m \mathrm{Hg}$ & $\underset{m m ~}{\operatorname{ml} / \min /}$ & $L / \min$ & & $m l$ & $m m \mathrm{Hg}$ & $\underset{m m ~}{m l / m i n} /$ & $L / \min$ \\
\hline $\begin{array}{l}6 \\
6 \\
7 \\
2 \\
3 \\
2\end{array}$ & $\begin{array}{l}5.46 \\
4.81 \\
5.16 \\
5.99 \\
5.51 \\
4.90\end{array}$ & $\begin{array}{l}133 \\
103 \\
120 \\
130 \\
119 \\
116\end{array}$ & $\begin{array}{l}32.8 \\
36.3 \\
48.6 \\
54.4 \\
59.1 \\
47.0\end{array}$ & $\begin{array}{l}13.8 \\
20.2 \\
16.2 \\
18.3 \\
20.1 \\
20.4\end{array}$ & $\begin{array}{l}7 \\
3 \\
7 \\
2 \\
2 \\
3\end{array}$ & $\begin{array}{l}5.55 \\
4.97 \\
5.16 \\
6.15 \\
5.36 \\
5.15\end{array}$ & $\begin{array}{l}633 \\
630 \\
633 \\
618 \\
620 \\
626\end{array}$ & $\begin{array}{l}17.3 \\
18.8 \\
25.6 \\
33.0 \\
33.1 \\
25.9\end{array}$ & $\begin{array}{l}12.5 \\
20.1 \\
16.7 \\
21.7 \\
20.6 \\
18.0\end{array}$ \\
\hline $\begin{array}{l}7 \\
4 \\
7 \\
2 \\
4 \\
2\end{array}$ & $\begin{array}{l}2.90 \\
2.92 \\
2.69 \\
3.21 \\
2.70 \\
2.70\end{array}$ & $\begin{array}{r}105 \\
79 \\
78 \\
81 \\
69 \\
70\end{array}$ & $\begin{array}{l}26.4 \\
29.4 \\
41.3 \\
47.3 \\
48.6 \\
38.3\end{array}$ & $\begin{array}{l}13.3 \\
20.7 \\
16.2 \\
18.9 \\
22.7 \\
16.9\end{array}$ & $\begin{array}{l}4 \\
2 \\
4 \\
2 \\
4 \\
2\end{array}$ & $\begin{array}{l}2.91 \\
2.84 \\
2.64 \\
3.07 \\
2.66 \\
2.59\end{array}$ & $\begin{array}{l}649 \\
583 \\
621 \\
613 \\
580 \\
589\end{array}$ & $\begin{array}{l}12.8 \\
16.5 \\
23.1 \\
25.8 \\
31.4 \\
22.4\end{array}$ & $\begin{array}{l}12.2 \\
22.3 \\
17.6 \\
18.3 \\
21.2 \\
15.3\end{array}$ \\
\hline
\end{tabular}

alveolar $\mathrm{CO}$ and acetylene concentrations measured after separate intervals of approximately $3,5,7,10$, and 15 seconds of breath holding. DLco and Qc at exercise at each lung volume are averages of three or more single breath measurements ( 5 to 10 seconds of breath holding); Qc was calculated by assuming that pulmonary tissue volume was the same during exercise as it was at rest. Measurements were duplicated at a high and at a low alveolar oxygen tension, i.e., when using approximately $98 \%$ and $30 \%$ oxygen mixtures, so that both pulmonary capillary blood volume and membrane diffusing capacity could be estimated by the method of Roughton and Forster (8). Measurements of DLco were corrected for the accumulation of carboxyhemoglobin in mixed venous blood as previously described $(1,10)$. Alveolar samples at the termination of breath holding were collected

TABLE III

Membrane diffusing capacity, pulmonary capillary blood volume, and pulmonary blood flow*

\begin{tabular}{|c|c|c|c|c|c|c|c|c|}
\hline \multirow[b]{2}{*}{ Subject } & \multicolumn{4}{|c|}{ Rest } & \multicolumn{4}{|c|}{ Exercise } \\
\hline & $V_{A}$ & Dмсо & $\mathrm{Vc}$ & $\overline{\mathbf{Q} c}$ & $\mathrm{VA}_{\mathbf{A}}$ & Dмсо & VA & $\dot{Q}_{c}$ \\
\hline At $T L C$ & $\stackrel{L}{B T P S}$ & $\underset{m m ~}{m l / m i n} /$ & $m l$ & $L / \min$ & $\stackrel{L}{B T P S}$ & $\underset{m m \mathrm{ml} / \mathrm{min} /}{\mathrm{m}}$ & $m l$ & $L / m i n$ \\
\hline $\begin{array}{c}\text { JM } \\
\text { AP } \\
\text { JT } \\
\text { GH } \\
\text { PG } \\
\text { Average } \\
\text { SE }\end{array}$ & $\begin{array}{l}6.67 \\
6.24 \\
7.66 \\
6.58 \\
6.44 \\
6.72\end{array}$ & $\begin{array}{r}59.5 \\
82.6 \\
95.1 \\
86.0 \\
69.7 \\
78.6 \\
\pm 6.3\end{array}$ & $\begin{array}{r}79.6 \\
80.7 \\
110.0 \\
84.4 \\
94.8 \\
89.9 \\
\pm 6.2\end{array}$ & $\begin{array}{l}5.8 \\
4.0 \\
7.7 \\
6.1 \\
6.8 \\
6.1\end{array}$ & $\begin{array}{l}5.97 \\
6.30 \\
7.40 \\
6.63 \\
6.13 \\
6.49\end{array}$ & $\begin{array}{r}61.2 \\
88.3 \\
94.3 \\
98.4 \\
69.8 \\
82.4 \\
\pm 7.2\end{array}$ & $\begin{array}{r}137 \\
162 \\
212 \\
192 \\
162 \\
173 \\
\pm 13\end{array}$ & $\begin{array}{l}20.2 \\
16.2 \\
18.3 \\
20.1 \\
18.1 \\
18.6\end{array}$ \\
\hline \multicolumn{9}{|l|}{$A t F R C$} \\
\hline $\begin{array}{c}\text { JM } \\
\text { AP } \\
\text { JT } \\
\text { GH } \\
\text { PG } \\
\text { Average } \\
\text { SE }\end{array}$ & $\begin{array}{l}3.55 \\
3.01 \\
3.84 \\
3.31 \\
3.26 \\
3.39\end{array}$ & $\begin{array}{r}46.4 \\
43.7 \\
62.4 \\
53.2 \\
47.1 \\
50.6 \\
\pm 3.3\end{array}$ & $\begin{array}{r}70.4 \\
110.0 \\
129.0 \\
101.0 \\
101.0 \\
102.2 \\
\pm 9.5\end{array}$ & $\begin{array}{l}6.4 \\
5.6 \\
5.6 \\
6.3 \\
5.2 \\
6.3\end{array}$ & $\begin{array}{l}3.52 \\
3.25 \\
3.83 \\
3.27 \\
3.22 \\
3.42\end{array}$ & $\begin{array}{r}44.4 \\
60.7 \\
69.4 \\
58.3 \\
49.8 \\
56.5 \\
\pm 4.3\end{array}$ & $\begin{array}{l}119 \\
160 \\
198 \\
254 \\
153 \\
177 \\
\pm 26\end{array}$ & $\begin{array}{l}20.7 \\
16.2 \\
18.3 \\
21.2 \\
15.4 \\
18.4\end{array}$ \\
\hline
\end{tabular}

* Abbreviations: $\mathrm{DM}_{\mathrm{Co}}=$ membrane diffusing capacity for $\mathrm{CO}, \mathrm{Vc}=$ pulmonary capillary blood volume, and BTPS $=$ body temperature, pressure, saturated with water. 
after expiration of 1.0 to $1.2 \mathrm{~L}$ to insure clearing of the dead space. This limited the lowest volume at which DLco could be measured.

All measurements at rest were made with the subject seated upright. Treadmill exercise was performed at 7 to 9 miles per hour on the flat for a duration of 5 minutes.

DLco changes with the level of pulmonary blood flow. Therefore, to insure that the measurements of DLco at different alveolar oxygen tensions used for calculating DMco and Vc were at comparable blood flows, we interpolated as shown in Figure 1.

\section{Results}

$\mathrm{DL}_{\mathrm{Co}}$ at different lung volumes at rest and during exercise is given for all subjects in Table II and graphically for subject JM in Figure 1 . It increases as the lung is inflated both at rest and exercise. This increase in $\mathrm{DL}_{\mathrm{CO}}$ is due to increased membrane diffusing capacity (Table III). $\mathrm{DM}_{\mathrm{Co}}$ increased from FRC to TLC in all five subjects both at rest and exercise. It is highly improbable that this could occur by chance $(\mathrm{p}<$ $0.01)$. The state of lung inflation did not significantly affect the volume of the pulmonary capillary bed at rest or its increase during exercise $(p>0.2$, Figure 2).

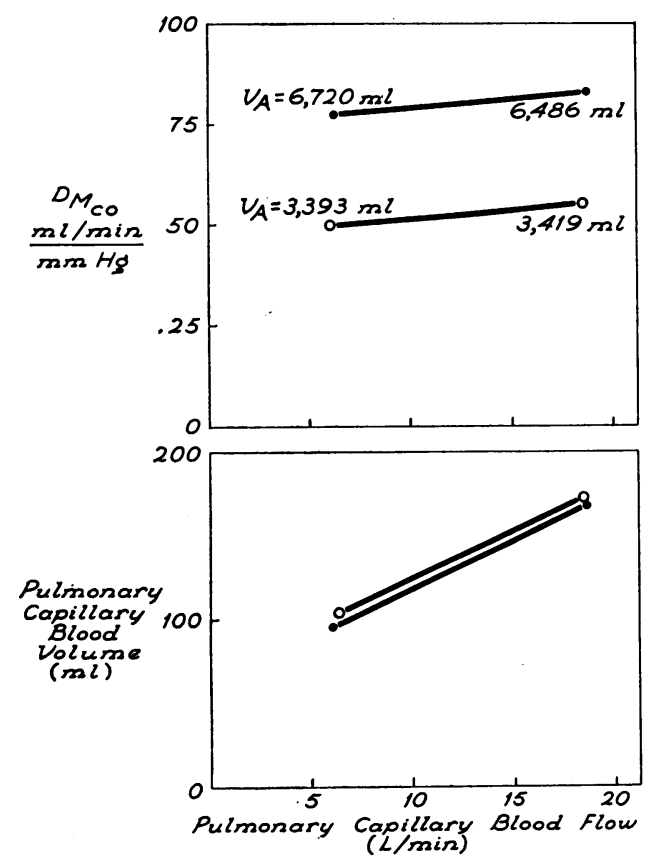

Fig. 2. Averages of membrane diffusing CAPACity AND CAPILLARY BLOOD VOLUME FOR FIVE SUBJECTS AT REST AND EXERCISE. VA $=$ alveolar volume.
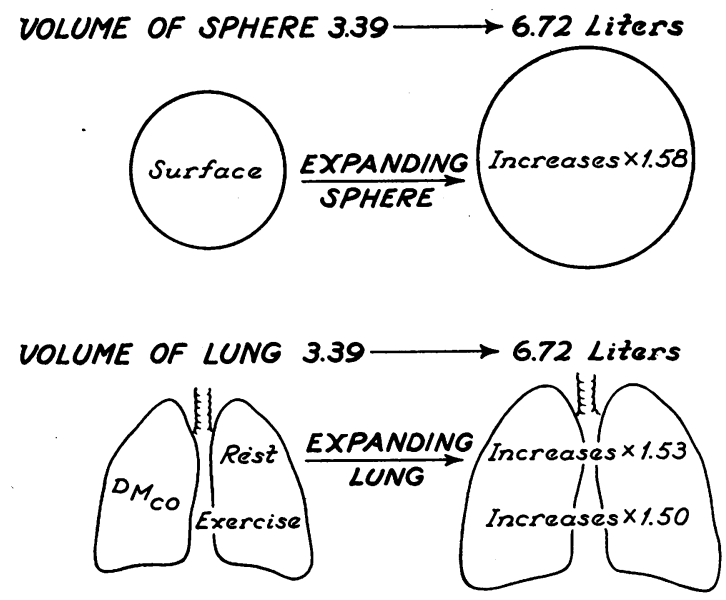

Fig. 3. The Relationship BetWeEN MEMbrane DifFUSING CAPACITY AND LUNG VOLUME LIKENED TO THE SURFACE AND VOLUME OF AN EXPANDING SPHERE.

\section{Discussion}

Membrane diffusing capacity. Hamer (3) and Ramlo and associates (4) have also reported that $\mathrm{DM}_{\mathrm{Co}}$ increases as the lung is inflated at rest. The increase reported by Hamer (3) is greater than that of the present series; the increase observed by Ramlo and associates (4) for normal subjects at rest is similar to that reported here. Staub and Storey, in studies on rapidly frozen cat lungs, observed a $70 \%$ increase in alveolar surface when alveolar volume is slightly more than doubled (11). Membrane diffusing capacity in our subjects increased in proportion to the expected increase in surface area as the lung expands, both at rest and exercise. This increase in pulmonary surface area and membrane diffusing capacity can be likened to the surface area increase of an expanding sphere (Figure 3 ). This concept that $\mathrm{DM}_{\mathrm{CO}}$ increases in direct proportion to the expansion of alveolar surface is a simple and easily visualized explanation of the data. The true mechanism whereby $\mathrm{Dm}_{\mathrm{co}}$ increases may be more complex: alterations in the absolute value or the distribution of the hematocrit within the capillary bed, or both, changes in the shape of the capillaries, and thinning of the alveolar membrane may also affect the $\mathrm{Dm}_{\mathrm{Co}}$ as the lung expands.

Pulmonary capillary blood volume. The pulmonary capillary blood volume did not change significantly from FRC to TLC in the present series. When a rubber tube is stretched the diameter decreases as the length increases. The 
change in the luminal volume of such a tube when it is stretched will depend upon which dimension changes more. A doubling of lung volume will increase the diameter of the alveoli by approximately $26 \%$ (11). The vessels contained within these alveoli must be stretched correspondingly. Cloetta (12) showed that when a rubber tube is stretched by this amount the luminal volume of the tube increases by only $3 \%$. The present studies suggest that lung capillaries behave in the same way as the rubber tubes used by Cloetta so that stretching the alveolar surface has a negligible effect on pulmonary capillary blood volume. This concept is consistent also with the results reported by Ramlo and co-workers (4). Hamer (3) observed a reduction in $\mathrm{Vc}$ as the lung was inflated at rest. The reason for this discrepancy in observations is not apparent.

Comparison of single breath with steady state lung diffusing capacity. Uniform distribution of ventilation, perfusion, and diffusing capacity with respect to lung volume is necessary for optimal utilization of the alveolar capillary surface in gas

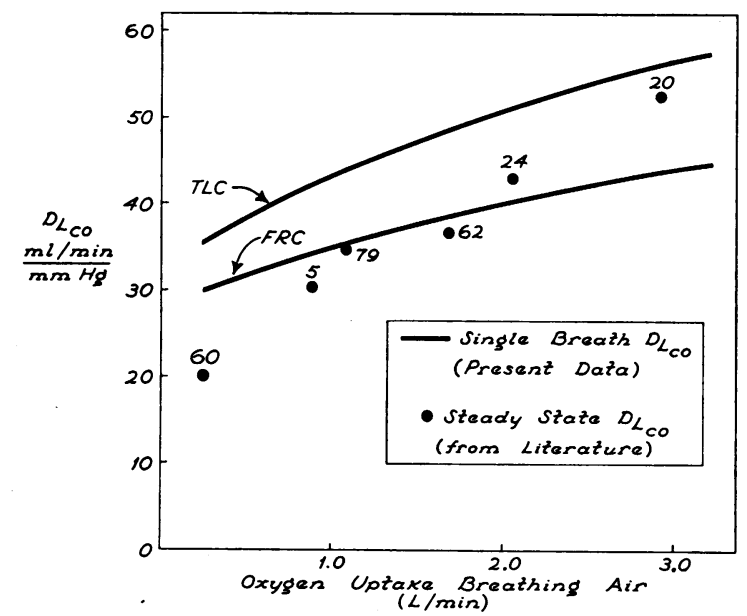

Fig. 4. Comparison of breath-holding Dlco at difFERENT LUNG VOLUMES With STEADY STATE DLCo AT NORMAL ALVEOLAR OXYGEN TENSIONS WITH SUBJECTS BREATHING AIR. The steady state values (O) are averages of data from other laboratories, both for the Bates method $(8,13-18)$ and Filley method $(7,19-21)$. Averages were made for each $500-\mathrm{ml}$ increment of oxygen uptake; the number accompanying each plotted point indicates the number of observations. There were 250 observations on 124 healthy young adults (mean age, 27 years; BSA, $1.89 \mathrm{~m}^{2}$ ). The pulmonary blood flow of our data was translated into terms of oxygen consumption in accordance with the measurements of Mitchell, Sproule, and Chapman (22).

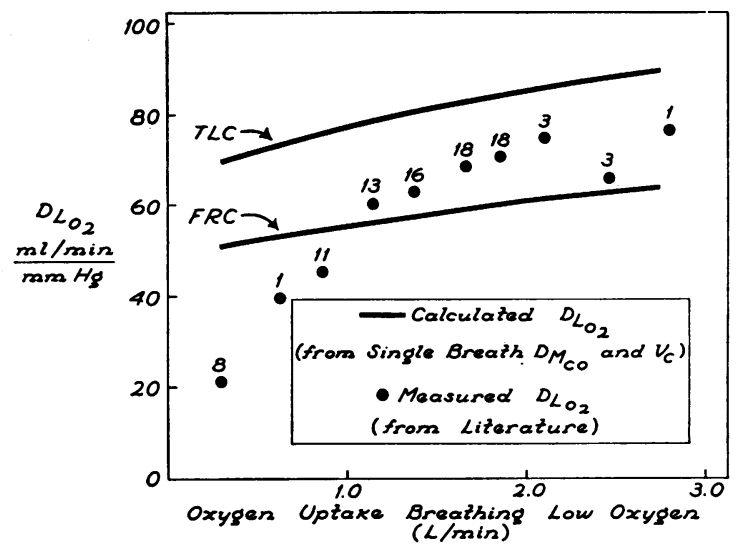

Fig. 5. COMPARISON OF OXYGEN DIFFUSING CAPACITY (DLO2) MEASUREd by THE LiLienthal-Riley techniQUe WITH THE DLO2 CALCULATED FROM OUR MEASUREMENTS OF DMco and Vc at different LUNG volumes. DL $\mathrm{L}_{2}$ was calculated from the relationship: $1 / \mathrm{DLO}_{2}=1 /\left(1.23 \mathrm{DM}_{\mathrm{Co}}\right)$ $+1 /\left(\theta \mathrm{O}_{2} \mathrm{Vc}\right)$, where $1.23=$ relative diffusivity of oxygen with respect to $\mathrm{CO}$ and $\theta \mathrm{O}_{2}=2.73$, corresponding to an $\mathrm{O}_{2}$ tension in the red cell of less than $50 \mathrm{~mm} \mathrm{Hg}$ (23). The steady state $\mathrm{DL}_{2}$ values (O) were obtained from the data of other laboratories $(6,7,19,24-27)$ and comprised 92 measurements made on 40 healthy young adults (average age, 28 years; average BSA, $1.93 \mathrm{~m}^{2}$ ). The values plotted are means for each $500-\mathrm{ml}$ increment of oxygen uptake; the number accompanying each plotted point indicates the number of observations. The relationship between cardiac output and oxygen consumption with subjects breathing low oxygen mixtures was obtained from data of Asmussen and Nielsen (28).

exchange. If the alveolar capillary surface is so optimally utilized during normal breathing and breath holding, diffusing capacity measured during normal breathing by the steady state methods should be the same as that measured during breath holding by the single breath method when both measurements are made at the same mean lung volume. Mean lung volume during normal breathing lies between FRC and TLC so that the steady state value for lung diffusing capacity (DL) should lie between the FRC and TLC values of the single breath method.

We compared measurements of steady state DL $L_{\text {Co }}$ reported from other laboratories with our measurements of single breath $\mathrm{DL}_{\mathrm{CO}}$ (Figure 4). We also compared measurements of $\mathrm{DL}_{\mathrm{O}_{2}}$ by the Lilienthal-Riley technique with $\mathrm{DL}_{\mathrm{O}_{2}}$ calculated from our single breath data (Figure 5).

During heavy exercise the steady state $\mathrm{DL}_{\mathrm{Co}}$ and $\mathrm{DL}_{\mathrm{O}_{2}}$ do in fact lie between the FRC and TLC values of the single breath method. At rest, how- 
TABLE IV

Comparison of steady state with single breath diffusing capacity in resting male subjects

\begin{tabular}{|c|c|c|c|c|c|c|}
\hline & $\mathrm{n}$ & Age & BSA & Lung volume & Dlco* & DLO2* \\
\hline \multirow{3}{*}{$\begin{array}{c}\text { Single breath DLco } \dagger \\
\text { (from literature) }\end{array}$} & \multirow{3}{*}{37} & years & $m^{2}$ & $L B T P S$ & $m l /(m m$ & $g \times \min )$ \\
\hline & & \multirow{2}{*}{28} & \multirow{2}{*}{1.92} & 6.53 & $34.4 \pm 0.5$ & \\
\hline & & & & 3.58 & $27.3 \pm 0.8$ & \\
\hline $\begin{array}{l}\text { Steady state DLco } \ddagger \\
\text { (from literature) }\end{array}$ & 60 & 29 & 1.92 & $3.48 \S$ & $20.5 \pm 0.7$ & \\
\hline \multirow{2}{*}{$\begin{array}{l}\text { Single breath } \mathrm{DL}_{\mathrm{O} 2} \\
\text { (calculated from } \\
\text { present data) }\end{array}$} & \multirow{2}{*}{5} & \multirow{2}{*}{23} & \multirow{2}{*}{1.91} & 6.72 & & $69.2 \pm 4.9$ \\
\hline & & & & 3.39 & & $50.7 \pm 3.4$ \\
\hline $\begin{array}{l}\text { Steady state DLo2 } \\
\text { (Lilienthal-Riley method, } \\
\text { from literature) }\end{array}$ & 8 & 31 & 1.98 & Midcapacity & & $21.9 \pm 2.9$ \\
\hline
\end{tabular}

* Mean value \pm standard error.

$\dagger$ Compiled from References 2, 3, 5, 13, 29, and 31 and including the five subjects of the present series.

$¥$ Compiled from References $8,13,14,17,18,19$, and 21 .

$\S$ FRC $+\frac{1}{2}$ tidal volume, compiled from References $13,14,17$, and 18 .

II Compiled from References 24 and 27.

I FRC + $\frac{1}{2}$ tidal volume. Values are not available.

ever, steady state $\mathrm{DL}_{\mathrm{CO}}$ and $\mathrm{DL}_{\mathrm{O}_{2}}$ are both low with respect to the single breath values.

Marshall (29) has presented evidence suggesting that the discrepancy between the single breath and steady state $\mathrm{DL}_{\mathrm{CO}}$ at rest can be explained solely on the basis of the different lung volumes at which the measurements are customarily made. Our results do not support this contention. As Marshall's series and our own are each comprised of only five subjects, the differing results may be due to sampling error. We have therefore reviewed the literature and compiled mean values for resting $\mathrm{DL}_{\mathrm{C} o}$ measured at both TLC and FRC in young healthy adult males (Table IV). Statistical analysis of the compiled values reveals the steady state $\mathrm{DL}_{\mathrm{Co}}$ to be significantly lower than the single breath values even when the latter are measured at FRC. Back pressure of $\mathrm{CO}$ is often neglected in steady state measurements of $\mathrm{DL}_{\mathrm{C} 0}$ and could be responsible for the steady state $\mathrm{DL}_{\mathrm{co}}$ being lower than the single breath $\mathrm{DL}_{\mathrm{co}}$. However, in studies on a large group of normal subjects (14) the resting steady state $\mathrm{DL}_{\mathrm{Co}}$ was depressed by $\mathrm{CO}$ back pressure by only $0.9 \mathrm{ml}$ per $\mathrm{mm} \mathrm{Hg} \times$ minutes, and this amount is clearly insufficient to account for the discrepancy between the steady state and single breath $\mathrm{DL}_{\mathrm{CO}}$.

We conclude that the resting steady state diffusing capacities for both $\mathrm{CO}$ and $\mathrm{O}_{2}$ are lower than the single breath diffusing capacities even when the measurements are made at the same lung volume.

If ventilation and perfusion are not uniformly distributed to the alveolar capillary surface, the steady state measurements of $\mathrm{DL}_{\mathrm{CO}}$ and $\mathrm{DL}_{\mathrm{O}_{2}}$ will be depressed (32). Nonuniform ventilation or perfusion will not affect the single breath $\mathrm{DL}_{\mathrm{CO}}$ provided the diffusing capacity is uniformly distributed with respect to lung volume (32). If the ratio of diffusing capacity to lung volume is nonuniform, the single breath measurement can be normal, falsely high, or falsely low depending upon the alveolar sample obtained.

A likely explanation for the steady state and single breath values for DL being different when measured at the same lung volume at rest and similar at exercise is that the relationships among ventilation, perfusion, and diffusing surface become more uniform from rest to exercise.

\section{Summary}

Membrane diffusing capacity increases as the lung volume expands from functional residual capacity (FRC) to total lung capacity (TLC). The increase is proportional to the estimated increase in alveolar surface area and occurs at both rest and exercise.

Pulmonary capillary blood volume is little affected by expansion of the lung from FRC to TLC either at rest or exercise. 
We have compared steady state lung diffusing capacity (DL) values from other laboratories with single breath $D_{L}$ values taking lung volume into account. The resting steady state $\mathrm{DL}_{\mathrm{CO}}$ is lower than the $\mathrm{DL}_{\mathrm{CO}}$ measured during breath holding. During exercise the steady state and single breath $\mathrm{DL}_{\mathrm{CO}}$ are similar.

Reported values for $\mathrm{DL}_{\mathrm{O}_{2}}$ measured by the Lilienthal-Riley technique are lower than the $\mathrm{DL}_{\mathrm{O}_{2}}$ calculated from single breath data at rest, but the two methods give similar values for exercise. This implies that measurements of single breath $\mathrm{DL}_{\mathrm{CO}}$ at operational lung volume during exercise may be translated into terms of oxygen transport.

The discrepancy between the steady state and breath-holding DL at rest and their similarity at exercise may be explained by postulating that the distribution of ventilation and perfusion with respect to diffusing capacity becomes more uniform from rest to exercise.

\section{References}

1. Johnson, R. L., Jr., W. S. Spicer, J. M. Bishop, and R. E. Forster. Pulmonary capillary blood volume, flow and diffusing capacity during exercise. J. appl. Physiol. 1960, 15, 893.

2. Ogilvie, C. M., R. E. Forster, W. S. Blakemore, and J. W. Morton. A standardized breath holding technique for the clinical measurement of the diffusing capacity of the lung for carbon monoxide. J. clin. Invest. 1957, 36, 1.

3. Hamer, N. A. J. Variations in the components of the diffusing capacity as the lung expands. Clin. Sci. 1963, 24, 275.

4. Ramlo, J. H., C. B. Weston, R. A. Cooper, T. C. Smith, and J. Rankin. The influence of alveolar volume on the diffusing capacity of the pulmonary membrane and pulmonary capillary blood volume in man (abstract). Fed. Proc. 1959, 18, 434.

5. McGrath, M. W., and M. L. Thomson. The effect of age, body size and lung volume change on alveolar-capillary permeability and diffusing capacity in man. J. Physiol. (Lond.) 1959, 146, 572.

6. Riley, R. L., R. H. Shepard, J. E. Cohn, D. G. Carroll, and B. W. Armstrong. Maximal diffusing capacity of the lungs. J. appl. Physiol. 1954, 6, 573.

7. Shepard, R. H., E. Varnauskas, H. B. Martin, H. A. White, S. Permutt, J. E. Cotes, and R. L. Riley. Relationship between cardiac output and apparent diffusing capacity of the lung in normal men during treadmill exercise. J. appl. Physiol. 1958, 13, 205.

8. Roughton, F. J. W., and R. E. Forster. Relative importance of diffusion and chemical reaction rates in determining rate of exchange of gases in the human lung, with special reference to true diffusing capacity of pulmonary membrane and volume of blood in the lung capillaries. J. appl. Physiol. 1957, 11, 290.

9. Lawson, W. H., Jr., and R. L. Johnson, Jr. Gas chromatography in measuring pulmonary blood flow and diffusing capacity. J. appl. Physiol. 1962, 17, 143.

10. Forster, R. E., W. S. Fowler, D. V. Bates, and B. Van Lingen. The absorption of carbon monoxide by the lungs during breathholding. J. clin. Invest. $1954,33,1135$.

11. Staub, N. C., and W. F. Storey. Relation between morphological and physiological events in lung studied by rapid freezing. J. appl. Physiol. 1962, 17, 381.

12. Cloetta, M. Untersuchungen über die Elastizität der Lunge und deren Bedeutung für die Zirkulation. Pflügers Arch. ges. Physiol. 1913, 152, 339.

13. Bates, D. V., N. G. Boucot, and A. E. Dormer. The pulmonary diffusing capacity in normal subjects. J. Physiol. (Lond.) 1955, 129, 237.

14. Donevan, R. E., W. H. Palmer, C. J. Varvis, and D. V. Bates. Influence of age on pulmonary diffusing capacity. J. appl. Physiol. 1959, 14, 483.

15. Bates, D. V., C. J. Varvis, R. E. Donevan, and R. V. Christie. Variations in the pulmonary capillary blood volume and membrane diffusion component in health and disease. J. clin. Invest. 1960, 39, 1401.

16. Mostyn, E. M., S. Helle, J. B. L. Gee, L. G. Bentivoglio, and D. V. Bates. Pulmonary diffusing capacity of athletes. J. appl. Physiol. 1963, 18, 687.

17. Apthorp, G. H., and R. Marshall. Pulmonary diffusing capacity: a comparison of breath-holding and steady state methods using carbon monoxide. J. clin. Invest. 1961, 40, 1775.

18. Macklem, P. T., and M. R. Becklake. The relationship between the mechanical and diffusing properties of the lung in health and disease. Amer. Rev. resp. Dis. 1963, 87, 47.

19. Filley, G. F., D. J. MacIntosh, and G. W. Wright. Carbon monoxide uptake and pulmonary diffusing capacity in normal subjects at rest and during exercise. J. clin. Invest. 1954, 33, 530.

20. Cugell, D. W., A. Marks, M. F. Ellicott, T. L. Badger, and E. A. Gaensler. Carbon monoxide diffusing capacity during steady exercise; comparison of physiologic and histologic findings in patients with pulmonary fibroses and granulomatoses. Amer. Rev. Tuberc. 1956, 74, 317.

21. Marks, A., D. W. Cugell, J. B. Cadigan, and E. A. Gaensler. Clinical determination of the diffusion capacity of the lungs; comparison of methods in normal subjects and patients with "alveolar-capillary block" syndrome. Amer. J. Med. 1957, 22, 51. 
22. Mitchell, J. H., B. J. Sproule, and C. B. Chapman. The physiological meaning of the maximal oxygen intake test. J. clin. Invest. 1958, 37, 538.

23. Staub, N. C., J. M. Bishop, and R. E. Forster. Velocity of $\mathrm{O}_{2}$ uptake by human red blood cells. J. appl. Physiol. 1961, 16, 511.

24. Lilienthal, J. L., Jr., R. L. Riley, D. D. Proemmel, and R. E. Franke. An experimental analysis in man of the oxygen pressure gradient from alveolar air to arterial blood during rest and exercise at sea level and at altitude. Amer. J. Physiol. 1946, 147, 199.

25. Cohn, J. E., D. G. Carroll, B. W. Armstrong, R. H. Shepard, and R. L. Riley. Maximal diffusing capacity of the lung in normal male subjects of different ages. J. appl. Physiol. 1954, 6, 588.

26. Siebens, A. A., N. R. Frank, D. C. Kent, M. M. Newman, R. A. Rauf, and B. L. Vestal. Measurements of the pulmonary diffusing capacity for oxygen during exercise. Amer. Rev. resp. Dis. 1959, 80, 806.

27. Turino, G. M., E. H. Bergofsky, R. M. Goldring, and A. P. Fishman. Effect of exercise on pul- monary diffusing capacity. J. appl. Physiol. 1963, 18, 447.

28. Asmussen, E., and M. Nielsen. The cardiac output in rest and work at low and high oxygen pressures. Acta physiol. scand. 1955, 35, 73.

29. Marshall, R. A comparison of methods of measuring the diffusing capacity of the lungs for carbon monoxide. Investigation by fractional analysis of the alveolar air. J. clin. Invest. 1958, 37, 394.

30. McGrath, M. W., and M. L. Thomson. Pulmonary diffusion at small lung volumes in asbestosis and chronic bronchitis with emphysema. Clin. Sci. 1961, 21, 15.

31. Cadigan, J. B., A. Marks, M. F. Ellicott, R. H. Jones, and E. A. Gaensler. An analysis of factors affecting the measurement of pulmonary diffusing capacity by the single breath method. J. clin. Invest. 1961, 40, 1495.

32. Forster, R. E. Exchange of gases between alveolar air and pulmonary capillary blood: pulmonary diffusing capacity. Physiol. Rev. 1957, 37, 391. 